Eduard A. Sosnin

\title{
Application of the Hardy-Weinberg law in the theory of social management
}

\section{KEYWORDS}

anthropotechnocenosis;

Hardy-Weinberg law;

technocenosis;

goal-oriented activity

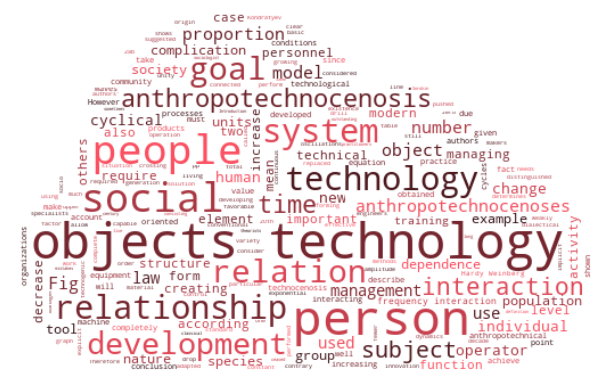

Word Cloud Generated by:

https://wordscloud.pythonanywhere.com/

\section{ABSTRACT}

Introduction. Currently, the number of functions performed by humans is gradually decreasing. Anthropotechnosis is a system of relations, which is aimed at the production of objects of technology, and not at the reproduction of a person. Due to the unity of the laws of developing goal-oriented systems of activity, the laws that work in describing biological and social systems can be extended to anthropotechnocenoses.

Materials and methods. A mathematical model of the HardyWeinberg law is used, which is implemented in biology to describe the crossing of individuals of two different species.

Results. As the proportion of objects of technology increases (the formation of the anthropotechnocenosis), the proportion of social units decreases, and the frequency of interaction between them increases. The drop in the frequency of interaction is due to the fact that the number and role composition of the subjects of the relationship "human-object of technology" changes. There is a gradual transfer of functions to objects of technology that were previously performed by a person. In the "ideal case", technology completely replaces a person. The model points to a very clear reason for the cyclical nature: the development of human $\leftrightarrow$ operator relations.

Discussion. The Hardy-Weinberg law, adapted to the description of anthropotechnocenoses, allows rethinking the dynamics of Kondratyev's cycles through the interaction of people and objects of technology. The obtained results can be used to receive basic data for a new scientific discipline - anthropotechnosociology.

Sosnin, E. A. (2021). Application of the Hardy-Weinberg law in the theory of social management. Economic consultant, 34 (2), 4-12. doi: 10.46224/ecoc.2021.2.1 


\section{INTRODUCTION}

M odern theorists and practitioners of social management sometimes make mistakes due to the fact that the community - society - has long ceased to be just a system consisting of individuals and social groups. People live in anthropotechnocenoses.

According to the classical definition of social relations, given by an outstanding sociologist of the 20th century Sorokin, "all social life and all social processes can be decomposed into phenomena and processes of interaction of two or more individuals". Therefore, "the model of a social group can be only two or more individuals who are interacting with each other" [7, pp. 140-141].

Nowadays, the variety of operators (any objects of technology, methods, techniques, etc.) of technogenic origin has made the thesis obvious: a person is not so much a subject of social relations, but a standard element of socio-technical (anthropotechnical) systems. The number of functions performed in them by a person is gradually decreasing. This tendency is figuratively called "displacement of a person from the system" [8]. There are so many objects of technology that, probably, if the number of devices and the number of people who use them is calculated, then from decade to decade the "population" of objects of technology overtakes the human population. That is, such a system of relations as anthropotechnocenoses has developed on the planet, which is aimed rather at the production of objects of technology, and not at human reproduction.

The term "technocenosis" was introduced in 1973 by Kudrin [6], defining the elements of the technical environment of a person, fixed in space, forming peculiar communities of weakly connected and weakly interacting products by technocenoses (from ancient Greek кorvos - common). In contrast to the item-element, which is discretely distinguished, "the technocenosis is distinguished formally, conventionally, by agreement". Technocenosis is a system of technogenic origin, which is considered as a community of units of equipment, technology, material, products, and waste, classified by types.

The question is, why are these aggregates of products loosely connected? Because the mediator between them is still a person. He or she is still engaged in goal-setting in relation to these cenoses, that is, he or she is at the management level.

The analysis of the main socio-philosophical models of interaction between society and technology shows that in the 19th-20th centuries, a number of optimistic/pessimistic, alarming/indifferent ideas regarding the relationship between technology and further human development appeared.

Much attention was paid to the problem of the relationship "human-technology" in Marxism, while the dialectical relationship, the dialectical unity of these opposites is affirmed - they are tools for transforming nature in accordance with the needs of a human and the society. However, "smart" machines require an "intelligent" person.

Currently, some authors $[12 ; 14 ; 15]$ write that there is a positive relationship between technological innovation and human development, while others $[11 ; 13]$ believe 
that the progress of technical capabilities is accompanied by a continuous process of dehumanization.

In 2000, it was shown that the relationship between a person and the operators used by them were in the nature of social relations, i.e., to achieve a certain goal, the interaction is not between a person $\leftrightarrow$ a person, but a person $\leftrightarrow$ an operator [4, pp. 39-50]. Indeed, the content (and typical development) of social relations ("a person $\leftrightarrow$ a person") is very similar to the relationship between a subject and an operator, for example, an object of technology (see the table below).

\begin{tabular}{|l|l|}
\hline \multicolumn{1}{|c|}{$\begin{array}{c}\text { Social system (the relationship "a person } \leftrightarrow \text { a } \\
\text { person") }\end{array}$} & $\begin{array}{c}\text { Anthropotechnical system (the relationship "a person } \\
\leftrightarrow \text { an object of technology") }\end{array}$ \\
\hline $\begin{array}{l}\text { The subject uses other subjects to achieve his or } \\
\text { her goal. Often, their goal changes in the course } \\
\text { of interaction, and a single goal of the formed } \\
\text { community appears - the survival }\end{array}$ & $\begin{array}{l}\text { The subject uses the technology to achieve a goal. } \\
\text { Having got used to using this or that tool, the subject } \\
\text { disaccustoms himself or herself of managing without } \\
\text { it and must keep the equipment in working order, } \\
\text { since only together they are effective }\end{array}$ \\
\hline $\begin{array}{l}\text { There is a social contract (explicit or implicit) } \\
\text { between the subjects of relations, i.e., the rules of } \\
\text { conduct that enable them to act effectively }\end{array}$ & $\begin{array}{l}\text { The subject is forced to use the object of technology, } \\
\text { following the operating instructions (explicit or } \\
\text { implicit), so as not to break the equipment or (in } \\
\text { some cases) not cause harm to his or her health }\end{array}$ \\
\hline $\begin{array}{l}\text { Those social groups (according to von Hayek) survive } \\
\text { that can compete in their productivity with other } \\
\text { groups, renewing their organizational structure when } \\
\text { conditions of existence change }\end{array}$ & $\begin{array}{l}\text { Part of the professions as ways of the existence of } \\
\text { the dyad "a person + an object of technology" (for } \\
\text { example, the crafts of nailers, barrel makers, churning } \\
\text { makers and others) have died out, replaced by } \\
\text { completely new forms of cooperation of people with } \\
\text { tools }\end{array}$ \\
\hline $\begin{array}{l}\text { In organizations, some people are "pushed out" to the } \\
\text { lower level of the hierarchy in order to perform the } \\
\text { simplest functions (errand boys, slaves, messengers), } \\
\text { while others are "pushed out" to the management } \\
\text { level (managers) }\end{array}$ & $\begin{array}{l}\text { When interacting with a person, some objects of } \\
\text { technology require only their muscular strength, } \\
\text { while others, on the contrary, only require the control } \\
\text { action of a person (a modern electric drill rotates the } \\
\text { drill itself, but it needs to indicate where and what to } \\
\text { turn) }\end{array}$ \\
\hline
\end{tabular}

The list of analogies in the above-mentioned table can be continued. It is important that biosystems, social organizations, and anthropotechnical systems are goal-oriented or teleonomic ${ }^{*}$, and their activity is inextricably linked with the activity of living organisms: in all cases, there is a conscious or unconscious pursuit of some goal.

Hence an important conclusion for the manager: modern effective management is the control over the state of anthropotechnocenosis (global or local), which cannot be reduced to only personnel management. In this sense, managing any projects today is also mandatory for managing objects of technology: the relationships of a person $\leftrightarrow$ an operator must be coordinated with each other, as well as the relationship of a person $\leftrightarrow$ a person (see, for example, [6]).

Due to the unity of the laws of developing goal-oriented systems of activity (GSA) [3-5], the laws that work in describing biological and social systems can be extended to anthropotechnocenoses.

\footnotetext{
* From ancient Greek $\tau \varepsilon \lambda$ os - goal, accomplishment. Goal-oriented systems are studied by teleological information theory developed by Korogodin in the late 1980s [4].
} 


\section{MATERIALS AND METHODS}

It is suggested to consider the specific Hardy-Weinberg law, which is used in biology to describe the crossing of individuals of two different species (in conditions of their isolation from other species) [8; 9].

In 1908, the British mathematician Hardy and the German physician Weinberg independently discovered that, in an ideal population, the frequencies of genes and genotypes remained constant from generation to generation. Their mathematical model was one of the starting points of population genetics [10].

In its most general form, the law is written as a quadratic equation:

$$
a^{2}+2 a b+b^{2}=1,
$$

where $a, b$ - shares of two species, $b=1-a$, i.e., other species do not affect their crossing; $2 a b$ - the proportion of unions and associations between species.

\section{RESULTS}

The same model can be used to describe the interaction of social units a (individuals, families, groups of organizations) with objects of technology $b$. At the same time, the objects of technology are understood broadly. These are objects developed not only by engineers but also by ordinary people ("naive engineers"), not only objects that make it possible to build machines and machine tools but also various kinds of inventory that allow creating and playing music, works of art, cooking food, making the daily routine easier, elective procedures, military operations and other goal-oriented practices of anthropotechnocenosis.

Fig. 1 shows the solution to equation (1). It can be seen that if $a=1$, then the proportion of objects of technology is $b=0$. As the proportion of objects of technology increases (the formation of anthropotechnocenosis), the proportion of social units decreases, and the frequency of interaction $v$ between them increases. However, at $a<0.5, b>0.5$, the frequency drops again. The drop in the frequency of interaction is due to the fact that the number and role composition of the subjects of the relationship "a person-an object of technology" changes. There is a gradual transfer of functions to objects of technology that were previously performed by a person. Ideally, the technology "completely replaces a person" [2].

In a particular case, the frequency of interactions $v$ is defined as:

$$
v=2 *(a b / S),
$$

where $0<S \leq 1$ is a parameter that determines whether the conditions are favorable for creating anthropotechnocenoses or not.

It is suggested to consider a situation in which the proportions of the elements that make up the anthropotechnocenosis, $\mathrm{a}$ and $\mathrm{b}$, change periodically in time, and the ratio $b=1-a$ remains. Then the dependence of the frequency of interactions on time will be as shown in Fig. 
2. At the same time, the authors considered the situation $S$ to be equally favorable during the entire time of the development of anthropotechnosis, i.e., $S=$ const.

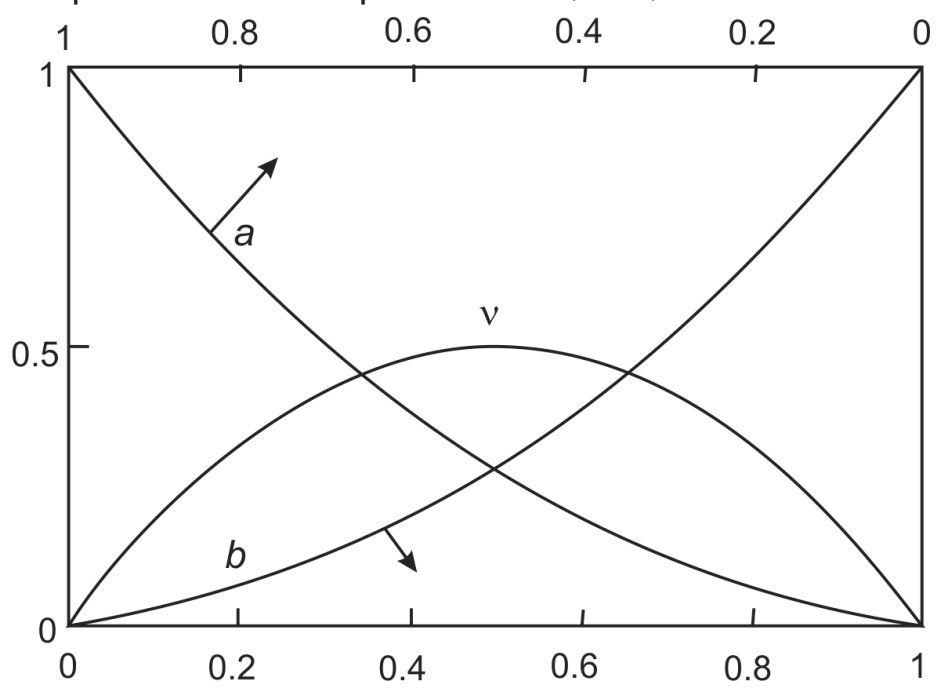

Figure 1 Solution to equation (1)

The use of simple tools by people means that $S \sim 1$, since almost everyone can learn and use them in everyday practice. However, with the development and complication of objects, fewer and fewer people are capable of both creating new objects of technology and using them. Moreover, the complication is increasing and requires more and more time to teach a person to handle objects of technology.

Another factor is the variety of modifications of the objects of technology that perform the same function, which also increases the time for users to master them. Therefore, it is proposed to complicate the model, assuming that the value of $S$ decreases according to the inverse exponential law, i.e., $S(t)=1 / \exp (t / c)$, where c is a constant that determines the rate of complication in the creation and operation of the objects of technology. Then the dependence $v(t)$ will take the form of oscillations increasing in amplitude (Fig. 2, the solid line in the upper graph).
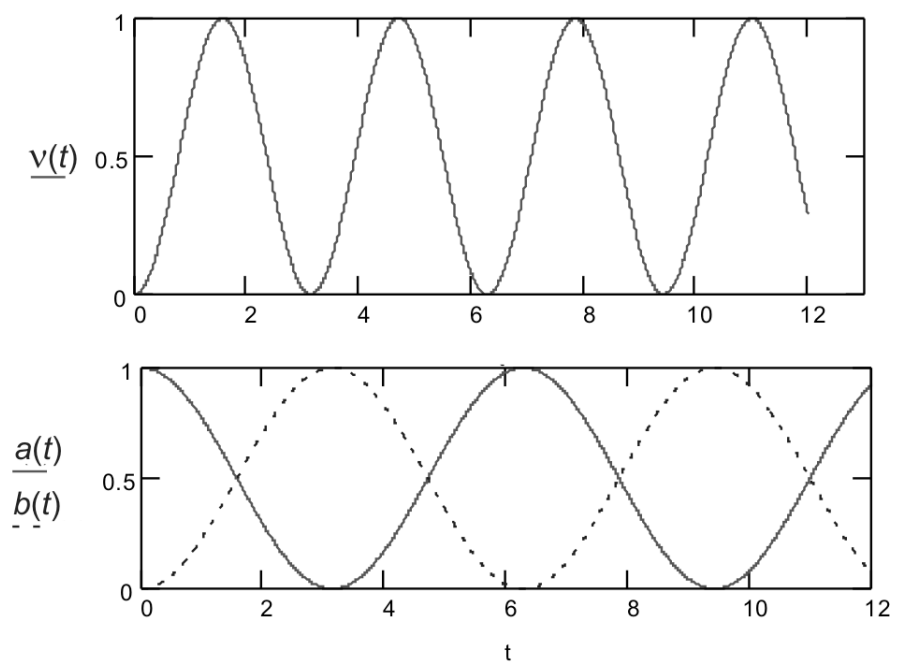

Figure 2 The cyclical nature of the interaction of people and objects of technology in the anthropotechnocenosis. Time is given in conventional units 
The authors' model does not take into account the fact that the proportion of the objects of technology, as well as the proportion of people in anthropocenoses, cannot reach zero values (this would mean complete "extinction" of people or cyclical complete refusal of objects the technology by people). If this is taken into account, then the $v(t)$ dependence will take the form of oscillations increasing in amplitude and not reaching zero values (Fig. 2, the dotted line in the upper graph). It is noteworthy that this dependence has a clear similarity with the so-called Kondratyev's cycles ( $K$-cycles or K-waves) - periodic ups and downs of the world economy [4], the presentation of which was first obtained empirically (1922). Schumpeter explained the K-waves by the activity of entrepreneurs (1939), Trotsky - by the class struggle (1923). There are other explanations, for example, related to political processes.

Meanwhile, the authors' model points to a completely clear reason for the cyclical nature: the development of relations a person $\leftrightarrow$ an operator.
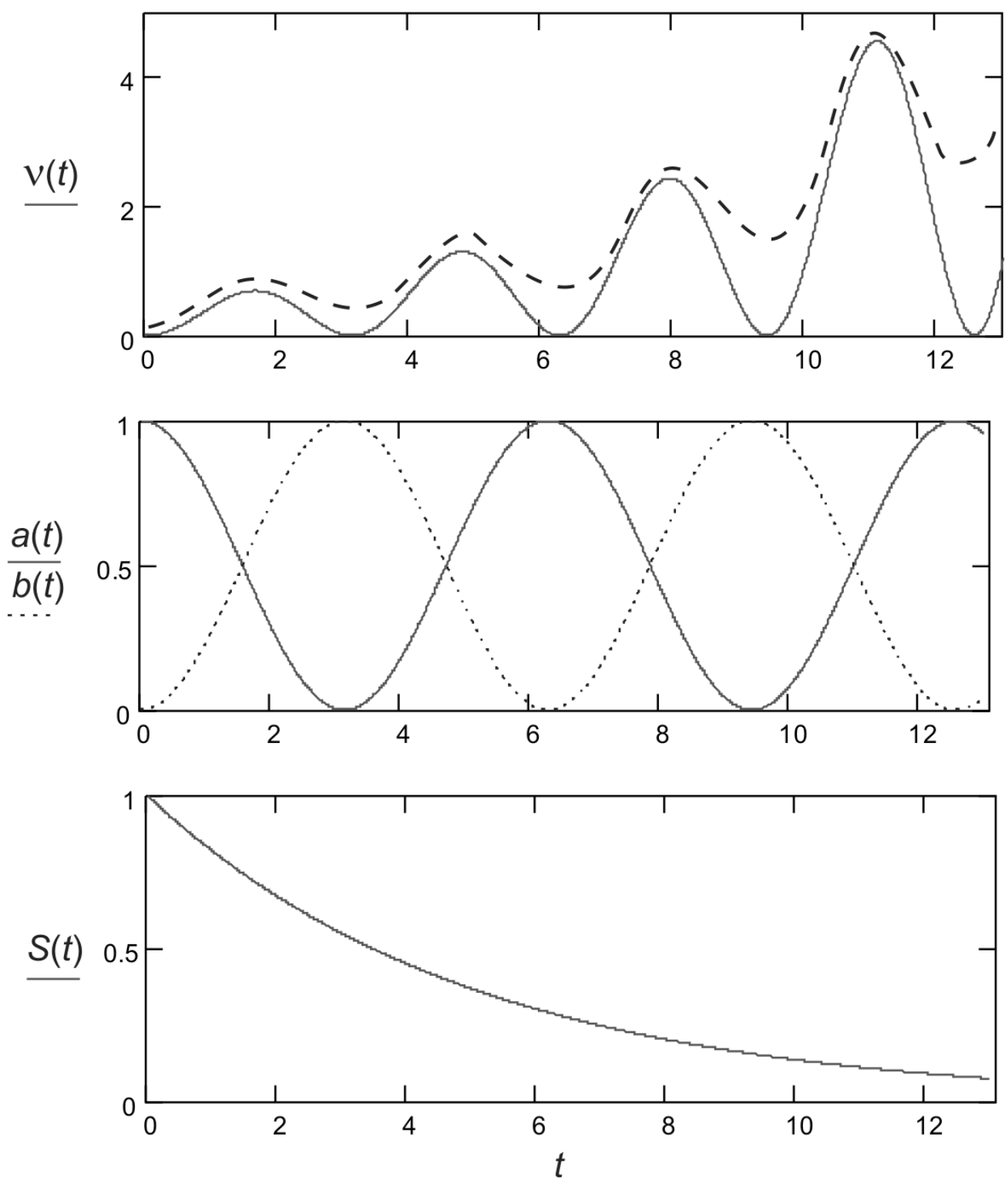

Figure 3 The cyclical nature of the interaction of people and objects of technology in the anthropotechnocenosis, taking into account the complication of objects of technology. Time is given in conventional units 


\section{DISCUSSION}

Thus, the Hardy-Weinberg law, adapted by the authors to the description of anthropotechnocenoses, allows rethinking the dynamics of Kondratyev's cycles through the interaction of people and objects of technology. As a particular case, the obtained dependence $v(t)$ (Fig. 3) corresponds to a continuous series of innovations, or a change in technological structures, when a huge number of objects of technology become obsolete and are replaced by fundamentally new ones. Such a restructuring of the anthropotechnocenosis, for example, leads to waves of dismissals and a decrease in the people's standard of living, until new technologies are developed and the personnel is trained to use and reproduce them. Then people are again involved in them: consumers, testers, and maintenance personnel.

\section{CONCLUSION}

To describe the dynamics of the development of anthropotechnocenoses, the adapted Hardy-Weinberg law was used. It is shown that it can be used to explain the change of technological structures in anthropotechnocenoses. It is important that the cyclical increase in the interaction of people and objects of technology in the anthropotechnocenosis occurs according to the model - only with an exponential decrease in factor S. This is important for the theory and practice of social management and means that as anthropotechnocenosis develops, the proportion of people capable of creating and managing the development of the objects of technology (in the total number of its components) is not growing - as it is commonly believed - but on the contrary, it is falling, although the total number of the population and objects of technology is growing.

This means that for the further cyclical development of anthropotechnocenoses with the complication of their structure for educating new specialists who ensure the development and renewal of the objects of technology, more expenditures and more time are required. I.e., from the point of view of education management, it is not the mass training of specialists that is required, but exclusively "individual", highquality training. In addition, the training of personnel for public administration must necessarily include the training in the basics of developing technical systems, since the level of relations between people and objects of technology, as well as the degree of coherence of these relations, are prevailing in forming crises in the modern society. The society that is an anthropotechnocenosis.

The obtained conclusions can be used to receive basic data for a new scientific discipline - anthropotechnosociology. 


\section{REFERENCES}

1. Altukhov, Yu.P. (2003). Genetic Processes in Populations. Moscow: IKTs Akademkniga.

2. Green, N., Stout, W., \& Taylor, D. (1996). Biology. In 3 Volumes. (Vol. 2, pp. 283-286). Moscow: Mir.

3. Zakharov, A.N., \& Sosnin, E.A. (2007). On the issue of displacing a person from systems. In New Ideas in the Analysis of Value Consciousness (Issue 4, pp. 441-452). Yekaterinburg: Ural Branch of the Russian Academy of Sciences.

4. Kondratyev, N.D. (2002). Big Cycles of Conjuncture and the Theory of Foreseeing. Moscow: Ekonomika.

5. Korogodin, V.I. (1991). Information and the Phenomenon of Life. Pushchino: Pushchino Scientific Center of the Russian Academy of Sciences.

6. Kudrin, B.I. (1993). Introduction to Technetics. Tomsk: Publishing house of Tomsk State University.

7. Sorokin, P.A. (1993). The System of Sociology. Vol. 1. Social Analytics: The Studies on the Structure of the Simplest (Generic) Social Phenomenon. Moscow: Nauka.

8. Sosnin, E.A., \& Poizner, B.N. (2000). Basics of Social Informatics: A Pilot Course of Lectures. Tomsk: Publishing house of Tomsk State University.

9. Sosnin, E.A. (2013). Management of Innovative Projects: A Study Guide. Rostov-onDon: Feniks.

10. Bacaer, N. (2011). The Hardy-Weinberg law (1908). In N. Bacaer, A Short History of Mathematical Population Dynamics (pp. 59-63). London: Springer. https://doi. org/10.1007/978-0-85729-115-8_11

11. Cascio, W.F., \& Montealegre, R. (2016). How technology is changing work and organizations. Annual Review of Organizational Psychology and Organizational Behavior, 3, 349-375. DOI: 10.1146/annurev-orgpsych-041015-062352.

12. Ejemeyovwi, J.O., Osabuohien, E.S., Johnson, O.D., \& Bowale, E.I.K. (2019). Internet usage, innovation and human development nexus in Africa: the case of ECOWAS. Economic Structures, 8, 15. https://doi.org/10.1186/s40008-019-0146-2

13. Bailey, J.E. (2011). Does health information technology dehumanize health care? Virtual Mentor, 13(3), 181-185. doi: 0.1001/virtualmentor.2011.13.3.msoc1-1103

14. Klochikhin, E.A. (20120. Linking development and innovation: what does technological change bring to the society? The European Journal of Development Research, 24, 4155. https://doi.org/10.1057/ejdr.2011.20

15.Qureshi, M.A., Qureshi, J.A., Ahmed, A., Qaiser, S., Ali, R., \& Sharif, A. (2020). The dynamic relationship between technology innovation and human development in technologically advanced countries: fresh insights from quantiles-on-quantile approach. Social Indicators Research, 152, 555-580 (2020). https://doi.org/10.1007/s11205-02002451-3 


\section{INFORMATION ABOUT THE AUTHOR}

Eduard A. Sosnin (Russian Federation, Tomsk) - Doctor in Physics and Mathematics, Professor of Innovation Management Faculty. Tomsk State University. E-mail: badik@loi. hcei.tsc.ru. Scopus ID: 7003325632. ReseacherID: L-8069-2019

\section{(c) (i) (2)}

Available: https://statecounsellor.wordpress.com/2021/05/30/sosnin-2/

Received: Jan 24, 2021 | Accepted: Apr 21, 2021 | Published: Jun 1, 2021

Editor: Viktor Tsvetkov, Moscow State Technical University of Radioengineering, Electronics and Automation, RUSSIA. Copyright: $\odot 2021$ Sosnin, E. This is an open access article distributed under the terms of the Creative Commons Attribution License, which permits unrestricted use, distribution, and reproduction in any medium, provided the original author and source are credited.

Competing interests: The authors have declared that no competing interests exist. 